\title{
PENGEMBANGAN PENGGUNAAN PENGINDERAAN JAUH UNTUK ESTIMASI PRODUKSI PADI (STUDI KASUS KABUPATEN BEKASI)
}

\section{Remote Sensing Application for Regional Rice Production Estimation (A Case Study in Bekasi District)}

\author{
Eka Rudiana1)*, Ernan Rustiadi2), Muhammad Firdaus ${ }^{3)}$ dan Dede Dirgahayu4) \\ 1) Alumni Program Studi Ilmu Perencanaan Wilayah, Sekolah Pascasarjana IPB, Jl. Meranti Kampus IPB Darmaga, \\ Bogor 16680 \\ ${ }^{2)}$ Departemen Ilmu Tanah dan Sumberdaya Lahan, Fakultas Pertanian IPB, Jl. Meranti Kampus IPB Dramaga, \\ Bogor 16680 \\ 3) Departemen Ilmu Ekonomi, Fakultas Ekonomi dan Manajemen IPB, Jl. Agatis Kampus IPB Dramaga, Bogor \\ 16680 \\ 4) Pusat Pemanfaatan Penginderaan Jauh (Pusfatja), LAPAN, Jalan Kalisari No.8, Pekayon, Jakarta Timur 13710
}

\begin{abstract}
The utilization of remote sensing imagery such Landsat-8 (OLI) to estimate harvested area and yield using Enhanced Vegetation Index (EVI) parameter is a new approach to estimate regional rice production. Based on the analysis of the satellite imagery acquisition during May-August 2015, the estimation of rice harvested area in Bekasi District during July-October 2015 is 15.86 thousand ha or 7.74 thousand ha (32.79\%) lower than BPS figures in the same period. Based on the relationship between yield (from the crop cutting survei, BPS) and EVI maximum, the equation model for rice yield estimation is: Yield $\left(q u\right.$ ha $\left.{ }^{-1}\right)=$ $36.818+44.965$ EVImax. $R^{2}$ value is 0.809. Based on the model, the estimation of rice yield in Bekasi District during JulyOctober 2015 is 47.40 qu ha-1. Compared to the data published by BPS, the result is 12.66 qu ha lower than the yield figure in

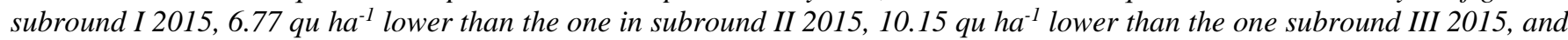
$6.62 \mathrm{qu} \mathrm{ha}^{-1}$ lower than the one in January-December 2015. Meanwhile, based on satellite imagery analysis, the estimation of rice production in the period of July-October 2015 is 75.16 thousand tons of GKG or 55.35 thousand tons of GKG (42.41\%) lower than BPS figures during the same period.
\end{abstract}

Keywords: Enhanced Vegetation Index, Landsat-8 (OLI), rice production estimation

\section{ABSTRAK}

Pemanfaatan produk penginderaan jauh satelit Landsat-8 (OLI) untuk melakukan pendugaan luas area panen dan produktivitas tanaman padi dengan menggunakan parameter Enhanced Vegetation Index (EVI) merupakan salah satu pendekatan baru untuk menghasilkan data estimasi produksi padi wilayah. Berdasarkan hasil analisis citra satelit dengan tanggal akuisisi bulan Mei-Agustus 2015, diperoleh hasil perkiraan luas panen padi sawah di Kabupaten Bekasi periode bulan Juli-Oktober 2015 adalah seluas 15.86 ribu ha atau lebih kecil 7.74 (32.79\%) ribu ha dibandingkan angka BPS pada periode yang sama. Berdasarkan keeratan hubungan antara nilai produktivitas hasil ubinan BPS dengan nilai EVI maksimum, diperoleh model persamaan pendugaan produktivitas tanaman padi sawah sebagai berikut: Produktivitas $\left(\mathrm{ku} \mathrm{ha}^{-1}\right)=36.818+44.965$ EVI maksimum. Nilai Rsquare yang diperoleh sebesar 0.809. Berdasarkan model tersebut diperoleh pendugaan produktivitas padi sawah di Kabupaten bekasi periode bulan Juli-Oktober 2015 sebesar $47.40 \mathrm{ku} \mathrm{ha}^{-1}$ atau lebih kecil $12.66 \mathrm{ku} \mathrm{ha}^{-1}$ dibandingkan angka produktivitas subround I 2015, lebih kecil $6.77 \mathrm{ku} \mathrm{ha}^{-1}$ dibandingkan angka produktivitas subround II 2015, lebih kecil $10.15 \mathrm{ku}^{-1}$ dibandingkan angka produktivitas subround III 2015, dan lebih kecil $6.62 \mathrm{ku} \mathrm{ha}^{-1}$ dibandingkan angka produktivitas periode Januari-Desember 2015 yang dipublikasikan BPS. Sementara itu, perkiraan produksi padi sawah periode panen bulan JuliOktober 2015 berdasarkan analisis citra satelit yakni sebanyak 75.16 ribu ton GKG atau lebih kecil 55.35 ribu ton GKG (42.41\%) dibandingkan angka yang dipublikasikan BPS pada periode yang sama.

Kata kunci: Enhanced Vegetation Index, Landsat-8 (OLI), estimasi produksi padi

\section{PENDAHULUAN}

Data produksi padi merupakan salah satu data strategis yang dapat dijadikan sebagai informasi rujukan dalam kegiatan penyusunan kebijakan pangan di Indonesia. Data tersebut diperoleh dari kegiatan statistik pertanian tanaman pangan yang di laksanakan oleh Badan Pusat Statistik (BPS) melalui kegiatan laporan statistik Pertanian (SP) tanaman pangan untuk memperoleh data luas panen melalui pendekatan pencatatan luas panen pada level kecamatan dan kegiatan survei ubinan untuk memperoleh informasi terkait produktivitas tanaman melalui pendekatan survei dengan mengukur produktivitas pada petak ubinan berukuran $2.5 \times 2.5 \mathrm{~m}$ sampel yang terpilih kemudian hasilnya dikonversi ke satuan kuintal per hektar.

Menurut Mosleh et al. (2015) dan Dirgahayu (2005) kedua pendekatan konvensional di atas mempunyai 3 kelemahan utama, yaitu: (i) memakan banyak waktu, 
biaya, dan tenaga (ii) informasi yang diperoleh sering kali mengalami keterlambatan, dan (iii) mengandung unsur subjektivitas serta berbagai kendala baik itu secara teknis atau non-teknis. Pemanfaatan teknologi penginderaan jauh merupakan salah satu upaya perbaikan kegiatan survei di bidang pertanian dalam rangka menyediakan data statistik pertanian yang handal dan akurat. Seiring perkembangannya, telah banyak sekali pendekatan metode dan produk penginderaan jauh yang dapat dimanfaatkan untuk tujuan tersebut. Menurut Poh et al. (2006) penginderaan jauh semakin berperan penting dalam berbagai bidang dimana salah satunya adalah dalam hal aplikasi pemantauan tanaman padi.

Tujuan dari penelitian ini adalah 1) Melakukan pendugaan umur dan fase tanaman padi dalam rangka monitoring pertumbuhan padi dan pendugaan luas panen di Kabupaten Bekasi; 2) Membuat model hubungan antara indeks vegetasi dengan produktivitas tanaman padi guna melakukan pendugaan produktivitas tanaman padi di Kabupaten Bekasi; 3) Melakukan perbandingan kuantitatif angka statistik tanaman padi menggunakan teknik penginderaan jauh dengan data yang dipublikasikan oleh BPS.

\section{BAHAN DAN METODE}

Penelitian ini dilaksanakan di Kabupaten Bekasi Provinsi Jawa Barat. Secara geografis Kabupaten Kabupaten Bekasi berada pada posisi 6 $6^{\circ} 10^{\prime} 53^{\prime \prime}-6^{\circ} 30^{\prime} 6^{\prime \prime}$ Lintang Selatan dan $106^{\circ} 48^{\prime} 28^{\prime \prime}-107^{\circ} 27^{\prime} 29^{\prime \prime}$ Bujur Timur.

\section{Bahan dan Alat}

Bahan yang digunakan dalam penelitian ini adalah data produktivitas hasil ubinan BPS subround III (periode panen September- Desember) tahun 2015, peta luas baku lahan sawah skala 1: 50,000, peta administrasi wilayah Kabupaten Bekasi skala1:100,000, dan citra Landsat-8 (OLI) dengan lokasi path/ row 122/ 44 selama periode bulan Mei sampai dengan Agustus tahun 2015. Hasil analisis citra tersebut nantinya digunakan untuk mengestimasi luas panen, produktivitas, dan produksi padi sawah pada periode Juli-Oktober 2015 di Kabupaten Bekasi. Pemilihan periode tanggal akuisisi di atas dilandaskan pada kendala adanya tutupan awan di permukaan bumi. Citra dengan tanggal akuisisi pada periode Mei-Agustus tahun 2015 memiliki kondisi permukaan bumi yang relatif bersih dari tutupan awan sehingga dapat dianalisis lebih lanjut. Sementara periode di luar itu, tidak dapat dianalisis lebih lanjut dikarenakan kondisi citra yang dihasilkan memiliki tutupan awan yang tebal dan menyelimuti hampir sebagian besar permukaan bumi. Peralatan yang digunakan dalam penelitian ini adalah perangkat penerima GPS, perangkat computer yang dilengkapi dengan software Windows Office 2007, SPSS, ENVI 11.0 dan ArcGIS 10.

\section{Metode Penelitian}

Pada tahap awal penelitian dilakukan ekstraksi nilai indeks vegetasi pada citra Landsat-8 (OLI) dengan tanggal akuisisi selama periode bulan Mei-Agustus 2015. Dirgahayu (2005) mengkombinasikan formula EVI akhir dengan SAVI dalam kondisi pengaruh atmosfer yang tidak signifikan yang diindikasikan oleh reflektansi kanal biru lebih besar dari reflektansi kanal merah. Sehingga algoritma komputasi EVI dapat ditulis sebagai berikut:

$$
\begin{gathered}
\text { If } \rho_{\text {blue }} \leq \rho_{\text {red }} \text { or } \rho_{\text {red }} \leq \rho_{\text {nir }} \text { Then EVI }=\frac{2.5\left(\rho_{\text {nir }}-\rho_{\text {red }}\right)}{\left(1+\rho_{\text {nir }}+6 * \rho_{\text {red }}-7.5 \rho_{\text {blue }}\right)} \\
\text { Else EVI }=\frac{1.5\left(\rho_{\text {nir }}-\rho_{\text {red }}\right)}{\left(0.5+\rho_{\text {nir }}+\rho_{\text {red }}\right)}
\end{gathered}
$$

Persamaan tersebut diaplikasikan kedalam citra Landsat-8 (OLI) multi temporal sehingga diperoleh data series data nilai EVI dan sebarannya pada lahan sawah di Kabupaten Bekasi.

Data EVI multi temporal yang diekstraksi pada tahapan sebelumnya dianalisis secara spasial dan dihitung nilai minimum, maksimum, dan letak maksimum dari seri data yang terkumpul. Dari nilai-nilai tersebut dapat diketahui fase pertumbuhan, awal tanam, panen, dan nilai statistiknya seperti nilai rata-rata, kovarian, slope dan skewness.

Menurut Dirgahayu (2005) model pertumbuhan tanaman padi berbentuk spline kubik berbentuk lonceng simetris. Untuk dapat membedakan fase antara fase vegetatif dan generatif setidaknya diperlukan dua citra yang berbeda tanggal akuisisinya ( $\mathrm{t}$ dan $\mathrm{t}-1$ ).

Kondisi fase pertumbuhan tanaman padi pada lahan sawah dapat dideteksi dari perubahan nilai EVI (DEVI). Fase vegetatif ditandai dengan perubahan nilai EVI yang positif dan fase generatif ditandai dengan perubahan nilai EVI yang negatif. Kriteria penentuan fase pertumbuhan padi adalah sebagai berikut:

$$
D E V I_{t}=E V I_{t}-E V I_{t-1}
$$

(a) Fase Dominan air, jika EVI(t) $\leq 0.19$

(b) Fase Bera, jika EVI(t) $>0.19$ dan $\operatorname{EVI}(\mathrm{t})<0.22$

(c) Fase Vegetatif, jika nilai DEVI $>0$

(d) Fase generatif, jika nilai DEVI $<0$

Adapun untuk penentuan umur tanaman padi didasarkan pada tabel kriteria yang dibangun oleh Dirgahayu (2005), yang disajikan pada Tabel 1. Estimasi waktu panen ditentukan berdasarkan letak EVI maksimum yang diasumsikan terjadi ketika tanaman padi berumur 60 HST. Dengan asumsi umur padi 110-120 HST, maka awal tanam dan waktu panen pada data EVI 16 harian dapat diketahui dengan formula:

$$
\begin{aligned}
& \mathrm{AT}=\mathrm{LM}-60 / 16=\mathrm{LM}-4 \\
& \mathrm{WP}=\mathrm{LM}+60 / 16=\mathrm{LM}+4
\end{aligned}
$$

dimana: $\mathrm{LM}=$ letak maksimum, $\mathrm{AT}=$ awal tanam, dan WP = waktu panen

Untuk membuat profil pertumbuhan tanaman padi EVI multitemporal berdasarkan piksel-piksel yang relatif homogen, maka data EVI tersebut harus diekstrak berdasarkan poligon yang memiliki waktu panen yang sama. Proses overlay dilakukan dengan menggunakan peta administrasi wilayah Kabupaten Bekasi untuk memperoleh estimasi luasan area panen per wilayah kecamatan. Sehingga dihasilkan data tabular berupa luasan areal panen yang dirinci berdasarkan wilayah kecamatan dan estimasi waktu panen tanaman padi di Kabupaten Bekasi. 
Tabel 1. Kisaran nilai EVI pada interval umur padi

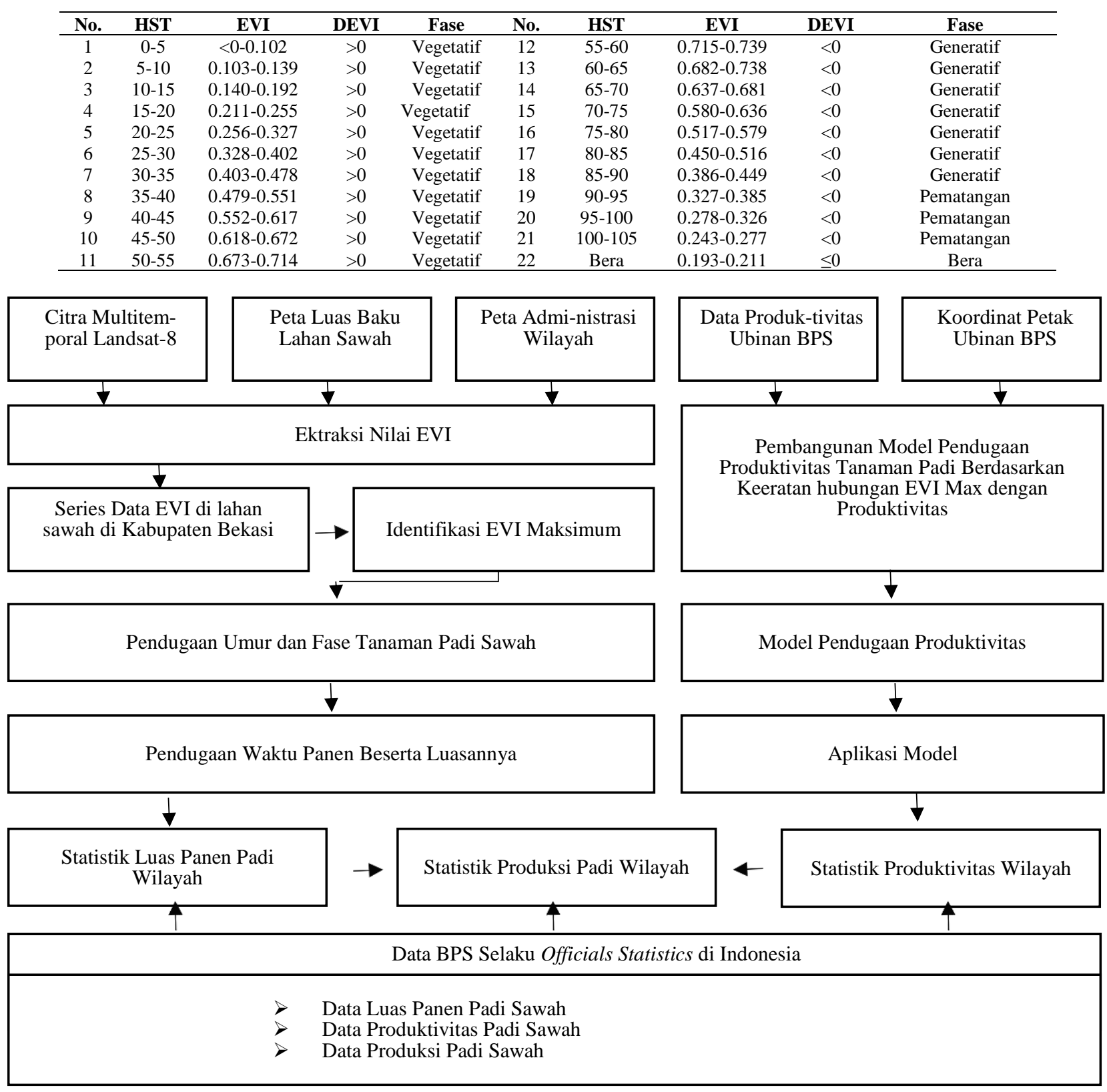

Gambar 1. Diagram metodologi penelitian

Tahapan selanjutnya adalah melakukan pendugaan terhadap nilai produktivitas tanaman padi sawah berdasarkan keeratan korelasi antara nilai EVI maksimum dengan produktivitas. EVI diukur dari citra satelit pada titik-titik lokasi sampel ubinan, sedangkan untuk produktivitas digunakan data lapangan berupa hasil ubinan setelah tanaman padi dipanen. Model persamaan regresi pendugaan produktivitas tanaman padi sawah pada penelitian ini dibangun berdasarkan data produktivitas tanaman padi pada sampel ubinan periode panen subround III (periode panen September-Desember).

Model regresi linier digunakan dengan metode pendugaan Ordinary Least Square (OLS), dengan formula:

$$
\text { Produkivitas }(k u / h a)=\alpha+\beta\left(E V I_{\max }\right)+\varepsilon
$$

Dimana : $\alpha=$ konstanta, $\beta=$ intercept, $\varepsilon=$ komponen error
Persamaan regresi yang diperoleh pada tahapan ini diaplikasikan pada peta sebaran EVI pada lahan sawah di Kabupaten Bekasi dan dioverlay dengan peta administrasi sehingga menghasilkan data tabulasi produktivitas per wilayah kecamatan di Kabupaten Bekasi.

Data produksi padi diperoleh dari hasil perkalian data luas panen dan produktivitas. Data estimasi luas panen dan produktivitas tanaman padi dihasilkan pada tahap sebelumnya dan ditabulasikan per kecamatan. Sehingga untuk memperoleh angka estimasi produksi per wilayah kecamatan kita hanya perlu mengalikan data estimasi luas panen dan produktivitas untuk masing-masing kecamatan.

Pada tahap akhir, nilai statistik tanaman padi (luas panen, produktivitas, dan produksi) yang diperoleh dari hasil analisis citra satelit diperbandingkan dengan data resmi yang dikeluarkan oleh BPS. Teknik kuantitatif digunakan untuk menganalisa sejauh mana perbedaan pada 
kedua data tersebut. Analisis ini dilengkapi dengan gambar grafik dan plot untuk memudahkan melihat hubungan diantara kedua data tersebut. Secara umum tahapan metode analisis data dalam penelitian ini disajikan pada Gambar 1.

\section{Hasil dan Pembahasan}

\section{Distribusi Spasial dan Pendugaan Luas Panen Tanaman Padi di Kabupaten Bekasi}

Berdasarkan analisis multitemporal citra satelit Landsat-8 (OLI) diperoleh hasil estimasi luas panen padi sawah periode Juli-Agustus 2015 di Kabupaten Bekasi yaitu seluas 15.86 ribu ha. Berdasarkan sebaran wilayahnya, Kecamatan Sukawangi, Sukakarya, dan Cabangbungin merupakan tiga kecamatan yang memiliki area panen padi sawah terluas di Kabupaten Bekasi yaitu masing-masing seluas 1.83, 1.80, dan 1.79 ribu ha. Kecamatan Tambun Selatan, Cikarang Utara, dan Cikarang Barat merupakan tiga kecamatan yang mempunyai luas panen terendah pada periode yang sama di Kabupaten Bekasi yaitu masingmasing sebesar 0.03, 0.04, dan 0.15 ribu ha. Sebaran spasial luas panen dan perkiraan panen tanaman padi sawah di Kabupaten Bekasi hasil analisis citra satelit di Kabupaten Bekasi disajikan pada Gambar 2.

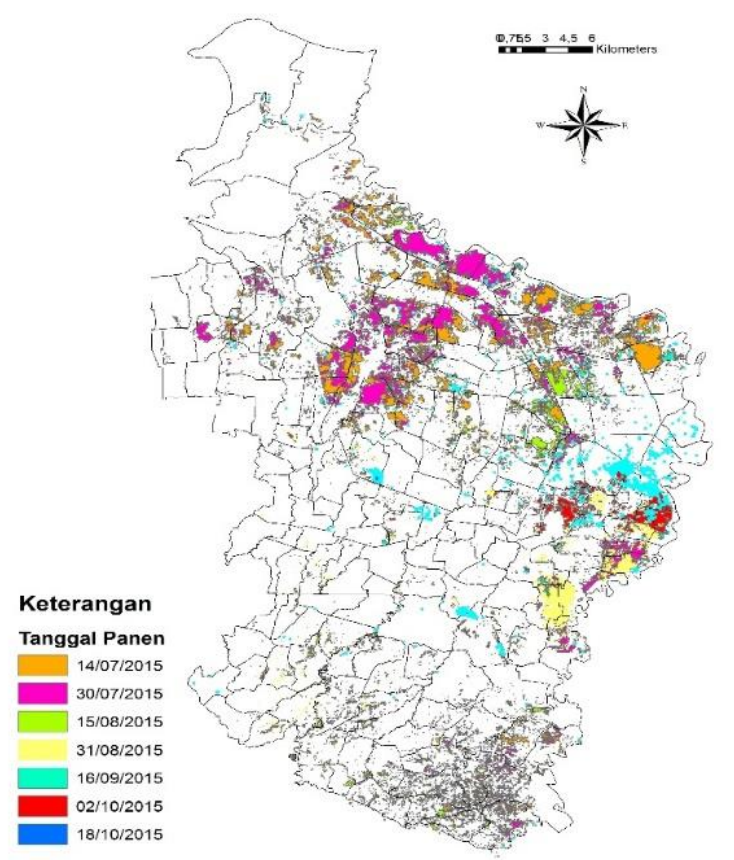

Gambar 2. Sebaran spasial luas panen tanaman padi sawah berdasarkan perkiraan waktu panen hasil analisis citra satelit

Jika dilihat berdasarkan perkiraan waktu panen periode Juli-Agustus 2015, sebagian besar tanaman padi sawah di wilayah Kabupaten Bekasi diperkirakan dipanen pada bulan Juli yakni seluas 10.62 ribu ha, disusul bulan Agustus seluas 3.48 ribu ha. Luas panen padi sawah terkecil diperkirakan panen pada bulan September yakni seluas 0.44 ribu ha. Rincian luas panen berdasarkan kecamatan dan bulan panen dapat dilihat pada Tabel 2 .
Tabel 2. Estimasi luas panen per kecamatan di Kabupaten Bekasi tahun 2015 berdasarkan hasil analisis citra satelit

\begin{tabular}{lrrrrr}
\hline \multirow{2}{*}{ No Kecamatan } & \multicolumn{3}{c}{ Luas Panen Bulan (ha) } & \multirow{2}{*}{ Jumlah } \\
\cline { 2 - 5 } & \multicolumn{1}{c}{ Juli } & Aug & Sept & \multicolumn{1}{c}{ Okt } & \\
\hline 1 Muaragembong & 437.04 & 20.25 & 6.84 & 5.22 & 469.35 \\
2 Kedungwaringin & 128.07 & 332.01 & 35.46 & 567.09 & $1,062.63$ \\
3 Cikarang Utara & 2.34 & 21.51 & 6.48 & 9.90 & 40.23 \\
4 Cabangbungin & $1,591.56$ & 141.03 & 37.53 & 16.74 & $1,786.86$ \\
5 Setu & 21.33 & 132.30 & 10.08 & 10.98 & 174.69 \\
6 Serang Baru & 315.00 & 178.74 & 3.33 & 0.63 & 497.70 \\
7 Cikarang Pusat & 180.90 & 159.48 & 12.33 & 5.13 & 357.84 \\
8 Cikarang Selatan & 60.21 & 72.54 & 5.40 & 41.94 & 180.09 \\
9 Cibarusah & 259.92 & 153.63 & 0.18 & & 413.73 \\
10Bojongmanggu & 804.42 & 145.53 & 1.62 & 0.54 & 952.11 \\
11Cikarang Timur & 257.22 & 782.91 & 84.78 & 281.34 & $1,406.25$ \\
12Karangbahagia & 134.46 & 267.84 & 29.97 & 202.05 & 634.32 \\
13Cibitung & 85.77 & 44.64 & 29.07 & 46.35 & 205.83 \\
14Cikarang Barat & 22.68 & 95.94 & 16.20 & 12.78 & 147.60 \\
15Tambun Selatan & 3.15 & 16.56 & 9.45 & 0.36 & 29.52 \\
16Tambun Utara & 331.11 & 25.20 & 8.46 & 2.88 & 367.65 \\
17Babelan & 382.77 & 18.54 & 2.07 & 1.44 & 404.82 \\
18Tarumajaya & 227.88 & 5.31 & 0.54 & 0.90 & 234.63 \\
19Tambelang & 865.62 & 40.68 & 13.14 & 10.17 & 929.61 \\
20Sukawangi & $1,789.29$ & 39.96 & 1.35 & 3.15 & $1,833.75$ \\
21Sukatani & 177.39 & 127.17 & 13.32 & 8.19 & 326.07 \\
22Sukakarya & $1,298.88$ & 461.79 & 29.07 & 11.97 & $1,801.71$ \\
23Pebayuran & $1,248.12$ & 196.47 & 85.32 & 69.66 & $1,599.57$ \\
\hline Total & $\mathbf{1 0 , 6 2 5 . 1 3}$ & $\mathbf{3 , 4 8 0 . 0 3}$ & $\mathbf{4 4 1 . 9 9}$ & $\mathbf{1 , 3 0 9 . 4 1}$ & $\mathbf{1 5 , 8 5 6 . 5 6}$ \\
\hline & & & & &
\end{tabular}

Secara umum data luas panen yang dihasilkan dari analisis citra satelit Landsat-8 (OLI) relatif lebih kecil dibandingkan data luas panen yang dikeluarkan oleh BPS. Total luas panen padi sawah di Kabupaten Bekasi pada periode bulan Juli sampai dengan Oktober tahun 2015 hasil analisis citra satelit adalah seluas 15.86 ribu ha atau lebih kecil 7.74 ribu ha $(32.79 \%)$ dibandingkan angka luas yang panen yang publikasikan oleh BPS pada periode yang sama yang mencapai angka seluas 23.59 ribu ha. Hasil perbandingan kedua data tersebut dapat dilihat pada Gambar 3.

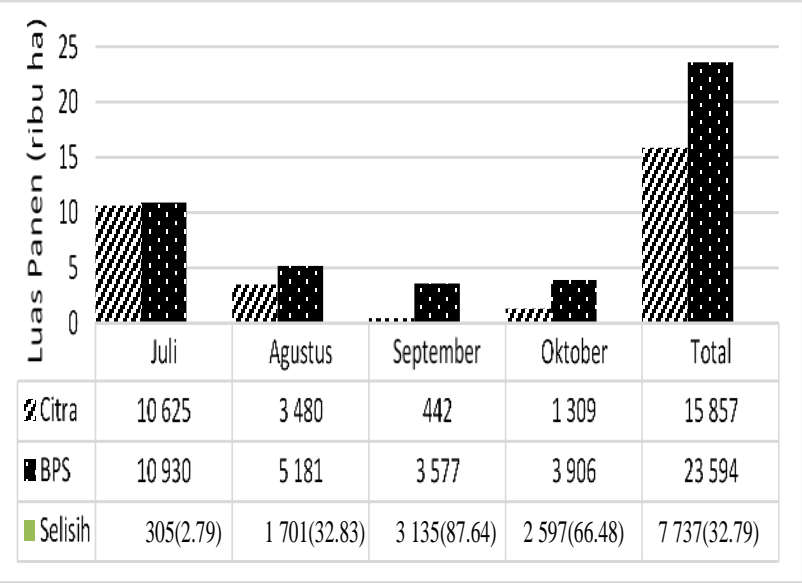

Gambar 3. Perbandingan luas panen hasil analisis citra dengan data BPS periode Juli-Oktober 2015

\section{Hubungan Nilai EVI dengan Produktivitas Tanaman Padi Sawah di Kabupaten Bekasi}

Untuk melihat hubungan antara nilai EVI maksimum dengan produktivitas tanaman padi, maka pada tahap awal dilakukan penghitungan nilai korelasi diantara kedua variabel tersebut. Berdasarkan analisis statistik yang dilakukan, diperoleh nilai korelasinya sebesar 0.899. Angka 
korelasi tersebut mengindikasikan bahwa terdapat hubungan positif antara nilai EVI maksimum dengan produktivitas. Semakin besar nilai EVI maksimum, maka semakin tinggi produktivitasnya. Di samping mempunyai arah positif, korelasi diantara kedua variabel tersebut juga diinterpretasikan sebagai hubungan korelasi yang kuat. Hal ini sesuai dengan pendapat Guilford (1980) dalam Marwah (2008) yang menginterpretasikan nilai korelasi antara 0.700.90 sebagai hubungan korelasi yang kuat.

Pada tahap selanjutnya dilakukan pemilihan model hubungan yang seusai antara variable EVI maksimum dengan produktivitas. Berdasarkan hasil analisis statistik, model yang sesuai untuk menggambarkan hubungan diantara keduanya adalah model regresi linier. Model regresi linier yang diperoleh adalah sebagai berikut:

Produktivitas $\left(\mathrm{ku} \mathrm{ha}^{-1}\right)=36.818+44.965$ EVI $_{\max }$

Grafik persamaan hubungan antara nilai EVI maksimum dengan produktivitas disajikan pada Gambar 4 .

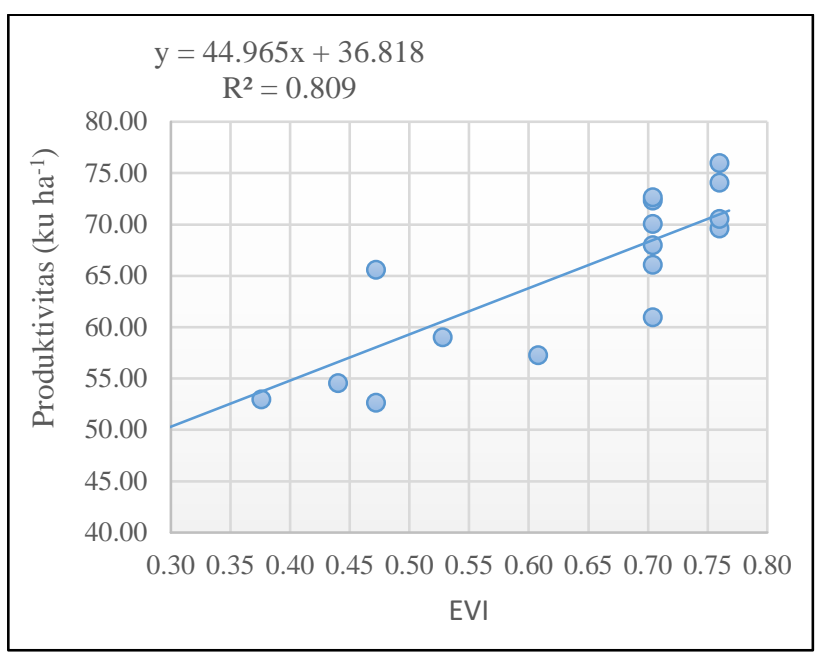

Gambar 4. Hubungan antara produktivitas tanaman padi sawah dengan nilai EVI maksimum

Berdasarkan model hubungan antara nilai EVI maksimum dengan angka produktivitas tanaman di Kabupaten Bekasi, diperoleh nilai konstanta $\mathrm{a}=36.818$ dan $\mathrm{b}=44.965$ dengan nilai Rsquare $=0.809$. Model persamaan diatas menunjukan bahwa produktivitas meningkat sebesar 44.965 satuan jika terjadi peningkatan nilai EVI maksimum satu satuan. Dari nilai $\mathrm{R}^{2}$ yang diperoleh menunjukan bahwa model regresi linier diatas mampu menjelaskan 80.9 persen keragaman yang ada, sementara sisanya dijelaskan oleh variabel lain. Hasil estimasi produktivitas tanaman padi sawah per kecamatan di Kabupaten Bekasi berdasarkan analisis citra dapat dilihat pada Tabel 3.

Berdasarkan Tabel 3, dapat dilihat bahwa rata-rata produktivitas tanaman padi sawah hasil analisis citra di Kabupaten Bekasi pada periode Juli-Oktober 2015 adalah sebesar $47.40 \mathrm{ku} \mathrm{ha}^{-1}$. Kecamatan Sukawangi merupakan kecamatan yang memiliki angka produktivitas tanaman padi sawah tertinggi di Kabupaten Bekasi yakni sebesar $57.55 \mathrm{ku}$ ha $^{-1}$, disusul oleh Kecamatan Tambelang dan Sukakarya masing-masing sebesar 53.71 dan $52.89 \mathrm{ku} \mathrm{ha}^{-1}$. Kecamatan Cikarang Pusat merupakan kecamatan yang mempunyai nilai produktivitas padi sawah terendah di Kabupaten Bekasi yaitu sebesar $31.43 \mathrm{ku} \mathrm{ha}^{-1}$ disusul oleh Kecamatan Setu dan Kecamatan Cibarusah masing-masing sebesar 32.90 dan $35.84 \mathrm{ku} \mathrm{ha}^{-1}$.
Jika diperbandingkan dengan data BPS, maka secara umum rata-rata produktivitas padi sawah hasil analisis citra mempunyai nilai yang lebih kecil jika dibandingkan dengan data produktivitas yang dipublikasikan BPS. Angka produktivitas tanaman padi hasil analisis citra lebih kecil $12.66 \mathrm{ku} \mathrm{ha}^{-1}$ (21.08\%) jika dibandingkan dengan angka produktivitas padi sawah pada subround I yang dipublikasikan BPS yaitu sebesar $60.06 \mathrm{ku}$ $\mathrm{ha}^{-1}$. Angka produktivitas tanaman padi hasil analisis citra lebih kecil $6.77 \mathrm{ku} \mathrm{ha}^{-1}(12.50 \%)$ jika dibandingkan dengan angka produktivitas padi sawah pada subround II yang dipublikasikan BPS yaitu sebesar $54.17 \mathrm{ku} \mathrm{ha}^{-1}$. Demikian pula pada periode Januari-Desember 2015, rata-rata produktivitas tanaman padi hasil analisis citra lebih kecil $6.62 \mathrm{ku} \mathrm{ha}^{-1}$ atau 12.25 persen jika dibandingkan dengan angka produktivitas padi sawah yang dipublikasikan BPS pada periode yang sama yaitu sebesar $54.02 \mathrm{ku} \mathrm{ha}^{-1}$. Untuk lebih jelas melihat perbedaan kedua data tersebut, berikut disajikan perbandingan data estimasi produktivitas padi sawah hasil analisis citra dan BPS pada Tabel 4.

\section{Pendugaan Produksi Padi Sawah di Kabupaten Bekasi}

Hasil estimasi produksi padi sawah di Kabupaten Bekasi pada periode Juli-Oktober 2015 berdasarkan hasil analisis citra satelit adalah sebesar 75.16 ribu ton GKG. Kecamatan Sukawangi merupakan kecamatan dengan estimasi produksi padi sawah tertinggi yakni sebesar 10.55 ribu ton GKG disusul oleh Kecamatan Sukakarya dan Kecamatan Cabangbungin masing-masing sebesar 9.53 dan 8.78 ribu ton GKG. Kecamatan Tambun Selatan merupakan kecamatan yang mempunyai estimasi produksi padi sawah terendah yakni sebesar 139.92 ton GKG disusul oleh Kecamatan Cikarang Utara dan Setu masing-masing sebesar 0.19 dan 0.57 ribu ton GKG. Estimasi produksi padi sawah di Kabupaten Bekasi berdasarkan analisis citra selama periode Juli-Oktober 2015 disajikan pada Tabel 5.

Angka estimasi produksi padi sawah berdasar hasil analisis citra satelit secara umum di bawah angka yang resmi yang dirilis oleh BPS. Data estimasi produksi padi sawah menurut BPS pada periode Juli-Oktober 2015 mencapai angka 130.51 ribu ton GKG. Jika diperbandingkan antara data keduanya, angka estimasi produksi padi sawah hasil analisis citra satelit lebih kecil sebesar 55.35 ribu ton (42.41\%) dibanding dengan angka produksi padi sawah yang dipublikasikan BPS. Perbedaan estimasi produksi padi sawah yang paling besar terjadi ada bulan panen September. Estimasi produksi padi sawah di Kabupaten Bekasi pada bulan September hasil analisis citra satelit sebesar 2.09 ribu ton GKG atau lebih kecil 18.49 ribu ton GKG $(89.82 \%)$ dari angka BPS yakni sebesar 20.59 ribu ton GKG pada periode yang sama. Perbedaan estimasi produksi padi sawah yang paling kecil terjadi pada bulan Juli. Pada bulan Juli, produksi padi sawah di Kabupaten Bekasi hasil analisis citra satelit sebesar 50.36 ribu ton GKG atau lebih kecil 8.85 ribu ton GKG (14.95\%) dibanding data produksi padi sawah yang dipublikasikan BPS yakni sebesar 59.21 ribu ton GKG pada periode yang sama. Grafik perbandingan estimasi produksi padi sawah hasil analisis citra dengan data BPS di Kabupaten Bekasi periode JuliOktober 2015 disajikan pada Gambar 5. 
Tabel 3. Estimasi produktivitas tanaman padi sawah per kecamatan di Kabupaten Bekasi berdasarkan hasil analisis citra satelit

\begin{tabular}{llc}
\hline No. & \multicolumn{1}{c}{ Kecamatan } & $\begin{array}{c}\text { Produktivitas Hasil } \\
\text { Analisis Citra }\left(\mathbf{k u ~ h a} \mathbf{~ h}^{\mathbf{1}}\right)\end{array}$ \\
\hline 1 & Babelan & 52.46 \\
2 & Bojongmangu & 39.75 \\
3 & Cabangbungin & 49.15 \\
4 & Cibarusah & 35.84 \\
5 & Cibitung & 50.03 \\
6 & Cikarang Barat & $47.40^{*}$ \\
7 & Cikarang Pusat & 31.43 \\
8 & Cikarang Selatan & $47.40^{*}$ \\
9 & Cikarang Timur & 43.63 \\
10 & Cikarang Utara & $47.40^{*}$ \\
11 & Karangbahagia & 47.45 \\
12 & Kedung Waringin & 42.13 \\
\hline
\end{tabular}

\begin{tabular}{llc}
\hline No. & \multicolumn{1}{c}{ Kecamatan } & $\begin{array}{c}\text { Produktivitas Hasil } \\
\text { Analisis Citra }\left(\mathbf{k u ~ h a}^{\mathbf{- 1}}\right)\end{array}$ \\
\hline 13 & Muara Gembong & $47.40^{*}$ \\
14 & Pebayuran & 50.45 \\
15 & Serang Baru & 36.58 \\
16 & Setu & 32.90 \\
17 & Sukakarya & 52.89 \\
18 & Sukatani & 50.25 \\
19 & Sukawangi & 57.55 \\
20 & Tambelang & 53.71 \\
21 & Tambun Selatan & $47.40^{*}$ \\
22 & Tambun Utara & 41.69 \\
23 & Tarumajaya & 44.31 \\
\hline \multicolumn{2}{c}{ Rata-rata } \\
\hline
\end{tabular}

Tabel 4. Perbandingan data estimasi produktivitas padi sawah di Kabupaten Bekasi hasil analisis citra satelit dan BPS

\begin{tabular}{ccccc}
\hline Periode & \multicolumn{2}{c}{ Produktivitas $\left(\mathrm{ku} \mathrm{ha}^{-1}\right)$} & \multicolumn{2}{c}{ Selisih } \\
\cline { 2 - 5 } Subround & Analisis Citra & BPS & $\mathrm{ku} \mathrm{ha}^{-1}$ & $(5)$ \\
\hline (1) & $(2)$ & $(3)$ & $(4)$ & -21.08 \\
I & 47.40 & 60.06 & -12.66 & -12.50 \\
II & 47.40 & 54.17 & -6.77 & -17.64 \\
III & 47.40 & 57.55 & -10.15 & -12.25 \\
Jan-Des & 47.40 & 54.02 & -6.62 & \\
\hline
\end{tabular}

Tabel 5. Estimasi produksi padi sawah di Kabupaten Bekasi berdasarkan hasil analisis citra periode Juli-Oktober 2015

\begin{tabular}{|c|c|c|c|c|}
\hline No. & Kecamatan & Luas Panen (ha) & Produk-tivitas $\left(\mathrm{ku} \mathrm{ha}^{-1}\right)$ & Produksi (ton) \\
\hline 1 & Babelan & 404.82 & 52.46 & $2,123.69$ \\
\hline 2 & Bojongmangu & 952.11 & 39.75 & $3,784.64$ \\
\hline 3 & Cabangbungin & $1,786.86$ & 49.15 & $8,782.42$ \\
\hline 4 & Cibarusah & 413.73 & 35.84 & $1,482.81$ \\
\hline 5 & Cibitung & 205.83 & 50.03 & $1,029.77$ \\
\hline 6 & Cikarang Barat & 147.60 & $47.40^{*}$ & 699.62 \\
\hline 7 & Cikarang Pusat & 357.84 & 31.43 & $1,124.69$ \\
\hline 8 & Cikarang Selatan & 180.09 & $47.40^{*}$ & 853.63 \\
\hline 9 & Cikarang Timur & $1,406.25$ & 43.63 & $6,135.47$ \\
\hline 10 & Cikarang Utara & 40.23 & $47.40^{*}$ & 190.69 \\
\hline 11 & Karang bahagia & 634.32 & 47.45 & $3,009.85$ \\
\hline 12 & Kedung Waringin & $1,062.63$ & 42.13 & $4,476.86$ \\
\hline 13 & Muara Gembong & 469.35 & $47.40^{*}$ & $2,224.72$ \\
\hline 14 & Pebayuran & $1,599.57$ & 50.45 & $8,069.83$ \\
\hline 15 & Serang Baru & 497.70 & 36.58 & $1,820.59$ \\
\hline 16 & Setu & 174.69 & 32.90 & 574.73 \\
\hline 17 & Sukakarya & $1,801.71$ & 52.89 & $9,529.24$ \\
\hline 18 & Sukatani & 326.07 & 50.25 & $1,638.50$ \\
\hline 19 & Sukawangi & $1,833.75$ & 57.55 & $10,553.23$ \\
\hline 20 & Tambelang & 929.61 & 53.71 & $4,992.94$ \\
\hline 21 & Tambun Selatan & 29.52 & $47.40^{*}$ & 139.92 \\
\hline 22 & Tambun Utara & 367.65 & 41.69 & $1,532.73$ \\
\hline 23 & Tarumajaya & 234.63 & 44.31 & $1,039.65$ \\
\hline & Jumlah/Rata-rata & $15,856.56$ & 47.40 & $75,160.09$ \\
\hline
\end{tabular}

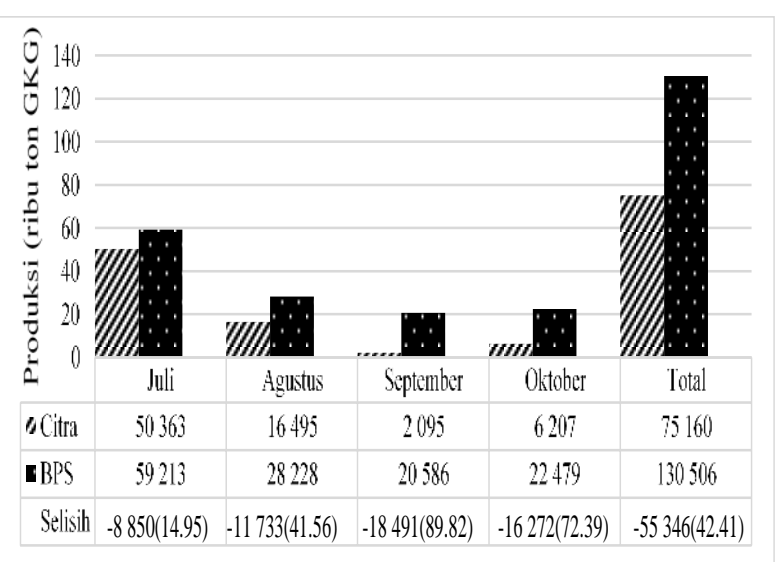

Gambar 5. Perbandingan estimasi produksi padi sawah hasil analisis citra dengan data BPS di Kabupaten Bekasi periode Juli-Oktober 2015

\section{SIMPULAN}

Pemanfaatan teknologi penginderaan jauh dapat dijadikan sebagai metode alternatif yang dapat digunakan untuk estimasi produksi padi wilayah. Secara umum hasil estimasi luas panen, produktivitas, dan produksi padi hasil analisis citra satelit lebih rendah dibandingkan data BPS. Berdasarkan hasil analisis citra satelit diperoleh perkiraan luas panen padi sawah di Kabupaten Bekasi periode bulan Juli-Oktober 2015 sebesar 15.86 ribu hektar atau lebih kecil 7.74 ribu hektar (32.79\%) dibandingkan angka BPS.

Model persamaan regresi linier hubungan antara nilai EVI maksimum dengan produktivitas padi adalah : Produktivitas $\left(\mathrm{ku} \mathrm{ha}{ }^{-1}\right)=36.818+44.965$ EVI $_{\max }$. Berdasarkan model tersebut diperoleh pendugaan produktivitas padi sawah di Kabupaten bekasi periode bulan Juli-Oktober 2015 sebesar $47.40 \mathrm{ku} \mathrm{ha}^{-1}$ atau lebih kecil $12.66 \mathrm{ku} \mathrm{ha}^{-1}$ dari angka produktivitas BPS subround I, lebih 
kecil $6.77 \mathrm{ku} \mathrm{ha}^{-1}$ dari angka produktivitas subround II BPS, lebih kecil $10.15 \mathrm{ku} \mathrm{ha}^{-1}$ dari angka produktivitas BPS subround III, dan lebih kecil $6.62 \mathrm{ku} \mathrm{ha}^{-1}$ dari angka produktivitas BPS periode Januari-Desember 2015.

Perkiraan produksi padi sawah di Kabupaten Bekasi berdasarkan hasil analisis citra satelit pada periode panen Juli-Oktober 2015 sebesar 75.16 ribu ton GKG atau lebih kecil 55.35 ribu ton GKG (42.41\%) dari angka yang dipublikasikan BPS yakni sebesar 130.51 ribu ton GKG.

\section{UCAPAN TERIMA KASIH}

Ucapan terima kasih kepada Pusdiklatren BAPPENAS RI yang telah membiayai penelitian ini melalui anggaran Beasiswa BAPPENAS Tahun 2014, kepada Dr. Dede Dirgahayu, M.Si (Pusfatja LAPAN) yang telah membantu dalam proses pengolahan data, BPS yang telah membantu dalam penyediaan data-data penelitian dan kegiatan survey di lapangan.

\section{DAFTAR PUSTAKA}

[BPS] Badan Pusat Statistik. 2015. Kabupaten Bekasi Dalam Angka 2015. BPS Kabupaten Bekasi. Bekasi. 2016. Provinsi Jawa Barat Dalam Angka 2016. BPS Provinsi Jawa Barat. Bandung.
Dirgahayu, D. 2005. Model pertumbuhan tanaman padi menggunakan data MODIS untuk pendugaan umur padi sawah. Prosiding Pertemuan Ilmiah Tahunan MAPIN XIV; Surabaya 14-15 Septermber 2005. Surabaya.

Huete, A.R. and E.P. Glenn. 2011. Recent Advances in Remote Sensing of Ecosystem Structure and Function. Advances in Environmental Remote Sensing: Sensors, Algorithms, and Applications. 291-319 p.

Lillesand, T. and W.K. Ralph. 1994. Remote Sensing and Image Interpretation. John Willey and Sons. New York, America.

Marwah, N. 2008. Estimasi Produksi Tanaman Padi Sawah di Kabupaten Bekasi, Karawang, dan Subang. Universitas Indonesia. Jakarta.

Mosleh, M.K., K.H. Quazi and H.C. Ehsan. 2015. Application of remote sensors in mapping rice area and forecasting its production: A Review. Sensor's Journal, 15: 769-791.

Poh, C.T., J.Y. Koay, K.S. Lim, B. Saiful, H.T. Ewe and H.T. Chuah. 2006. Applications of Remote Sensing in The Monitoring of Rice Crops. The Institution of Engineers. 67(4). 